\title{
Energy saving claims for lighting controls in commercial buildings.
}

\author{
Gordon Lowry
}

London South Bank University

\begin{abstract}
Lighting systems consume a significant proportion of the energy used in commercial buildings, and the control of lighting use is an important determinant of the energy performance of buildings. A review and meta-analysis of lighting energy studies in commercial premises is undertaken to investigate difficulties with reported energy-saving claims for popular lighting control methods. Earlier studies have indicated that in some installations automated controls may save very little energy if they are replacing manual control. However, even where manual control would be a reasonable expectation, such as in private offices, it has been common practice to report saving in energy compared to the lights being used throughout the working day, which leads to overstatement of the energysaving potential. However, generally, user behaviour cannot be reliably predicted, which makes it difficult to quantify properly the benefits of adding automatic controls. It is argued that savings should instead be quantified with reference to published norms for lighting use in commercial buildings.
\end{abstract}

\section{Keywords}

lighting, energy performance, energy conservation, energy use behaviour, lighting controls 


\section{Introduction}

Energy used in buildings contributes significantly to worldwide carbon emissions; buildings are responsible for more than one-third of global energy consumption (International Energy Agency [IEA], 2013). Much of the energy use in buildings is associated with determining internal environmental conditions to ensure occupant comfort. To find ways to reduce this energy use, there is a need to examine, quantify and compare the energy saving benefits of proposed means of systems control. However, predicting this energy use in individual premises is made difficult where users are provided with the means to alter their environment. As will be demonstrated in this paper, the influence of individual control on lighting use may be highly uncertain, and yet an important determinant of lighting energy use. For the UK it is estimated that in 2014 lighting consumed $21 \%$ of energy used in commercial buildings (Department of Energy and Climate Change [DECC], 2015) and it can account for over $40 \%$ of electricity costs in naturally ventilated offices (Chartered Institution of Building Services Engineers [CIBSE], 2012). Finally, because lighting energy is derived wholly electrically, lighting has greater potential than other forms of internal environmental control for causing carbon emissions, and therefore needs to be carefully managed. Common methods to reduce energy use in lighting include:

- adoption of new lamp technologies, e.g. light-emitting diodes;

- controls to reduce hours of use when space is unoccupied;

- controls to reduce over illumination when daylight is available.

Control can be automated, rely on manual switching, or be some combination of the two. This paper will examine the estimation of lighting energy use where manual control is an option. Arguably the increased use of automated controls, especially in commercial buildings, makes the use of manual control alone less significant. However, the consideration of manual controls remains important because:

- there are still many buildings that continue to rely solely on manual switching; 
- manual control has an important role in improving user satisfaction (Boyce et al., 2006);

- when improved forms of control are used, energy use needs to be benchmarked, presumably against the manual control that the new controls replace or supplement.

The role of manual controls in benchmarking will be considered in detail in this paper. A series of lighting energy studies will be reviewed and the results show wide variations. Understandably these may arise because the duration of daily lighting need in premises varies greatly. Occupancy hours are not constant, daylight availability differs and individual users operate local controls to suit their individual preferences. Occupant behaviour is known to be responsible for large differences between predicted and actual performance in many building energy use studies (Gaetani, Hoes, and Hensen, 2016). Occupancy effects are also conflated with users' responses to the presence or use of automatic occupancy sensing, which can make them less inclined to trouble to switch lighting off (Crisp, 1978). NMR Group, Inc (2014) completed a study in New York State on dwellings and found greater use for low energy lamps, suggesting that there may be some rebound, or Jevons effect (Sorrel, 2009).

In this paper, a review is undertaken of published research into lighting energy use in commercial premises. The studies include those leading to prediction of manual switching behaviour and those that merely attempt to quantify the effects of alternative control methods: typically automatic switching or dimming responding to occupancy detection or daylight. The published energy saving results for different forms of popular lighting control in smaller scale studies are compared with larger field studies to determine appropriate means of benchmarking the energy performance of lighting controls.

\section{Lighting energy-use studies}

A number of studies have been carried out in recent years to investigate the use of energy in lighting, often in conjunction with calculations of energy savings resulting from the implementation 
of a particular control method. The approach taken to assess the energy savings associated with improvement measures undertaken in lighting installations may be characterised as either of the following:

- single or small numbers of buildings leading to detailed modelling of effects;

- large-scale field studies of many buildings simply characterised by industry sector.

The first can provide good evidence for the impact on lighting energy use of measured factors or aspects of the installations such as application, duration of occupation, building orientation and design, interior reflectances, occupant behaviour, and tuning and configuration during installation and commissioning (Williams, Atkinson, Garbesi, Page, \& Rubinstein, 2012). Often these studies attempt to quantify energy use under various forms of automatic control, where the lighting use is likely to be deterministically modelled. However, the results are often from too small a sample to be generalizable.

The studies reviewed later for this paper include data from monitoring of real installations in various buildings as noted in Tables 4-6, and results from laboratory test beds or mock ups with just one or two spaces (Boyce et al., 2006; Jennings, Rubinstein, DiBartolomeo \& Blanc, 2000; Lee \& Selkowitz, 2006; Nagy, Yong, Frei, \& Schlueter, 2015; Newsham, Aries, Mancini \& Faye, 2008; Onaygil \& Güler, 2003). Additionally, some studies use simulation models to predict the effects of particular factors on the lighting use, such as glazing, room surface reflectance and location (Acosta, Munoz, Campano, \& Navarro, 2015; Krarti, Erickson, \& Hillman, 2005), control settings (Garg \& Bansal 2000; Reinhart, 2004; Roisin, Bodart, Deneyer, \& D'Herdt, 2008) and the use of light pipes (Vasilakopoulou, Synnefa, Kolokotsa, Karlessi \& Santamouris, 2016).

Large scale field studies have the potential to provide statistically significant average results but cannot assess the effects of individual differences between premises such as the variance in activity of occupants and daylight availability. Studies considered here (EMI Consulting, 2014; Itron, 2010; 
Kema Inc., 2010; Von Neida, Maniccia \& Tweed, 2001) collected data from many premises, usually over a period of months and then extrapolated these to annual data by fitting a sinusoidal curve to the part-year data collected. The curve accounts for expected seasonal variation in lighting use by fitting the sinusoidal variation with its maximum and minimum at the respective solstice dates (Shepherd, Rambo, \& Busker, 2013).

Finally there have also been studies specifically undertaken to ascertain the switching behaviour of people in offices, which may allow energy use under manual control to be estimated, but with some stochastic uncertainty (Boyce et al., 2006; Gaetani et al., 2016; Hunt, 1980; Love, 1998; Reinhart \& Voss, 2003). Tzempelikos (2010) reports findings from a simulation utilising the switching probability relations and daylight illuminance calculated in IES-VE for a large office area including perimeter cellular offices. The energy reduction from the use of the manual switches compared with no use of controls was $57 \%$ for the perimeter offices and $45 \%$ for interior zones. This is better than the simulated result from daylight-linked control that reduced energy use by only $24 \%$ in the perimeter zones. These results are based on modelling assumptions in the settings of the controls that might not represent a real case, but serve to demonstrate how overlooking simple manual switching might distort the assessment of energy saving potential.

A study by Williams et al. (2012) has reviewed commercial lighting energy saving studies carried out over recent decades to ascertain average lighting energy savings for different control types based on all available published data. The study included reports of savings from 133 instances of actual installations, as opposed to simulated and these are summarised in Table 1. Tellingly, for all types of control the average savings from actual installations were lower than those calculated in simulated cases, on average by $10 \%$. 
Table 1 Summary of average energy savings reported for lighting control methods

Source: Williams et al.(2012).

\begin{tabular}{lcc}
\hline Control method & $\begin{array}{c}\text { Savings } \\
\text { all building types }\end{array}$ & offices \\
\hline occupancy sensing & $24 \%$ & $22 \%$ \\
daylighting linked dimming & $28 \%$ & $27 \%$ \\
personal control & $31 \%$ & $35 \%$ \\
\hline
\end{tabular}

Williams et al. acknowledged that the studies reviewed did not always make clear what benchmark the saving was referenced to, though many were, as is typical in the examples reviewed later in this paper, referenced to lighting being on continuously during normal hours of operation. Necessarily these uncertainties mean that the average values cannot be taken as reliable predictors of future saving potential, but the fact that the popular saving strategies of occupancy sensing and daylight linked dimming appear to save less than manual controls is reason to question the claims made for automated control. Similarly, Reinhart (2004) using a model of user switching behaviour, found that occupancy sensing control used alone increased energy consumption compared with manual switching.

Standard data for evaluating energy performance of lighting systems in Europe, in accordance with the EC Directive on Energy Performance of Buildings 2002/91/EC, has been compiled in BS EN 15193 (BSI, 2007). For offices, the standard uses default annual space operating hours: 2250 hours in daylight and 250 not in daylight. To all of these an occupancy dependency factor is applied, determined by the type of occupancy and form of lighting control. Additionally, a daylight dependency factor is applied to the daylit hours where controls respond to daylight availability. From these factors the equivalent annual full-load light operating hours can be calculated, as shown in Table 2. Noticeable is the recognition that in small offices, daylight dependent control alone need not reduce the energy use below that achieved with manual control. Compared with the assumed 2500 operating hours, daylight dependent control alone generates a $10 \%$ saving, while in a singleoccupancy office manual control alone generates a $20 \%$ saving. When combined the saving 
increases to $27 \%$. Thus the additional contribution from adding this automatic control to a room already equipped with a manual switch is relatively small.

Table 2 BS EN 15193 example equivalent annual full-load lighting operating hours

\begin{tabular}{lccc}
\hline \multicolumn{1}{c}{ Control method } & \multicolumn{2}{c}{ Office size } \\
& one person & 2-6 persons & large open-plan \\
\hline manual switching only & 2000 & 2250 & 2500 \\
occupancy detection: manual on, automatic off & 1500 & 1750 & 2500 \\
daylight linked dimming (0.9 factor by default) & 2275 & 2275 & 2275 \\
manual + daylight linked dimming & 1820 & 2048 & 2275 \\
\hline
\end{tabular}

Within the UK the assessment of energy performance of buildings is guided by CIBSE Guide F (CIBSE, 2012) which identifies for offices values of typical and good practice. For lighting systems, this leads to values for the annual equivalent full-load lighting use as shown, for example, in Table 3 for naturally-ventilated type offices. The typical figures are very close to those given in BS EN 15193 for occupancy sensing controlled lighting, while the good practice show aspirational values for improved designs.

Table 3 CIBSE Guide F examples of equivalent annual full-load lighting operating hours

\begin{tabular}{lcc}
\hline & \multicolumn{2}{c}{ Office size } \\
& cellular & open plan \\
\hline typical & 1500 & 2100 \\
good practice & 1125 & 1800 \\
\hline
\end{tabular}

\section{Manual control studies}

The number of studies of the usage pattern of manual switching in the literature is much smaller than the number undertaken for more modern automated controls. Mostly the studies were carried out some decades ago and so there may be good reason to question whether attitudes and behaviours towards energy use were the same as now. Unfortunately, there has not been the work done to update the findings of the older studies. 
One of the most frequently cited studies was by Hunt (1979) who measured lighting use in seven different premises. Of these, three were multi-occupancy medium-sized offices with different degrees of daylight availability. Time lapse photography at 8-minute intervals was used to record occupancy and lighting use over half years, i.e. January to June or July to December. Hunt noted that lighting switching rarely occurred after occupants' first arrival. Values of external illuminance were derived from global irradiance data taken from local monitoring stations and assumed daylight efficacies. Probit analysis was used to fit a normal cumulative curve of switching probability to the simultaneous value of the base- 10 log of the derived external illuminance. Across the different rooms this form of curve was found to fit consistently but for each room there was quite different sensitivity to external illuminance. Arguing that users are likely to judge the need for artificial lighting based on internal daylight illuminance, Hunt demonstrated that a common switching probability model could be used for any of the rooms if this was related to the minimum working plane illuminance. Unfortunately internal illuminance was not measured, so had to be calculated from external diffuse illuminance and measured daylight factors. Because of difficulties in the way that Hunt derived the external illuminance and measured daylight factors the model cannot be used directly with measured internal illuminance values (Littlefair, 1998). However, these problems are circumvented if the probability aggregated over a whole year is predicted from the minimum daylight factor and time of day that the switching happens, using the historical records for occurrence of external daylight illuminance (Hunt, 1980).

Reinhart and Voss (2003) monitored user switching and their data showed a close resemblance to that of Hunt. Similarly, a logit regression was used by Love (1998), based on desk top daylight illuminance though with only two users and there were marked differences in the fit parameters. Individual differences remain a problem where the intention is to predict how a particular set of users are likely to behave. Despite being based on a very limited sample of users from the 1970s, Hunt's data remain the basis for a tool for estimating lighting energy use current in Building Research Establishment digest 498 (Littlefair, 2014) and thus as part of the recommended means for 
selecting lighting controls for compliance with UK Building Regulations (NBS, 2013). Hunt's model has also been used in later models of switching behaviour such as Lightswitch-2002 (Reinhart, 2004) and then Daysim (http://daysim.ning.com/).

Significantly, Moore, Carter and Slater (2002), Newsham et al. (2008) and Nagy et al. (2015) all found that where users can control dimming, this form of manual control reduces energy consumption because users often choose illuminance levels lower than those recommended by lighting standards.

Some researchers have endeavoured to model user behaviour mathematically (Lindehöf \& Morel, 2006; Reinhart, 2004) but allowance has to be made for users whose switching is independent of daylight availability. These studies suggest that users can be classified into those that are active and those that are passive, though it is not clear how the split would be in any given or hypothetical population of occupants.

With all of the switching probability studies, the accuracy of prediction is dependent on application to groups of users of sufficient number for the aggregate effect of their behaviour to resemble some average. However, a problem remains that switching probability models, such as Hunt's, derive originally from observations of small samples.

Published studies have also collected data on the measured hours of use of lighting. Annual averages may be useful for the establishment of norms for baselining energy use where the manual switching is complimented by some additional controls. Hunt's work already described found that the three offices in the UK had quite different patterns ranging from 5.78 hours per day for a general clerical office to 8.41 hours per day for an office used for "computer programming". In a study in the US, Jennings et al. (2000) monitored lighting use in the period June to December for a single office building used as a test bed and found daily hours of use as an average of 8.9 hours for manually switched lighting. As these studies averaged the data over complete half years between solstices they can be used to estimate annual hours of use: assuming a 260 day working year for an office, 
these studies suggest annual hours of use in the range $1500-2300$, so are consistent with the hours of use for small offices derived in BS EN 15193, shown in Table 2. However, clearly there is significant difference between premises. Another US study (Maniccia, Rutledge, Rea \& Morrow, 1999) recorded lighting use in various spaces within a floor of an office block from December to March. They found that, though the office operated a notional 10-hour day, offices were occupied only $46 \%$ of this time and that, even when occupied, lights were left switched off $24 \%$ of the time. Thus the average daily hours of use might be taken to be only 3.5 .

\section{Small-scale energy saving studies}

Studies are frequently undertaken into the effectiveness of particular control methods. Clearly an important outcome is the effect on energy use, which is often expressed as an energy saving. These are not values that can be extrapolated far as the studies are frequently of very limited scale, sometimes involving single rooms. Critically for this paper, the baseline used for the calculated savings varies with many studies assuming lights would be on all day or all occupied hours while some make allowance for lighting being manually switched off at times. These are identified for a range of studies in Tables 4-6.

Some of the studies involve measured performance while others rely on simulations. Many do not attempt to allow for the use of manual switching, as would be appropriate where there would be little daylight availability, or the lighting is in large deep plan spaces where individual switching is not possible. It is useful, therefore, to consider separately such studies from those where individual switching might be assumed. The sample sizes are small and there are wide variations in the reported savings and therefore the median values will be used for comparison.

\subsection{Studies of spaces where individual switching is not relevant}

Littlefair (1990) in a discussion of means of estimating lighting energy consumption where daylight sensing control is used, cites various older studies carried out by the Building Research 
Establishment in the UK that showed lighting energy savings of $30-46 \%$ in a variety of non-domestic buildings. Studies carried out more recently for single premises include some with measured data and others relying on simulation models. Measured data studies (Fernandes, Lee, DiBartolomeo, \& McNeil, 2014; Galasiu, Newsham, Suvagau, \& Sander, 2007; Lee \& Selkowitz, 2006; Li \& Lam, 2001; Li, Lam, \& Wong, 2006) show values of energy saving resulting from occupancy sensing, daylight sensing or both combined. Similar figures were found to those in the studies cited by Littlefair despite the variation in location and building use. Examples of studies using modelled energy performance of the lighting systems (Krarti et al., 2005; Vasilakopoulou et al., 2016) report a much wider range of possible values as the studies enable more extreme cases than are normally found to be investigated. Summary data are shown in Table 4 and the median reported saving is $50 \%$.

Table 4 Studies in single buildings without prospect of individual switching

\begin{tabular}{|c|c|c|c|c|}
\hline Reference & Application & $\begin{array}{l}\text { Control or } \\
\text { saving method } \\
o=\text { occupancy } \\
\text { sensing } \\
d=\text { daylight- } \\
\text { linked dimming }\end{array}$ & Baseline & Savings reported \\
\hline & Measured & & & \\
\hline Li and Lam (2001) & $\begin{array}{l}\text { large office floor } \\
\text { (Hong Kong) }\end{array}$ & d & lights on continually & $\begin{array}{l}\text { up to } 50 \% \text { depending on } \\
\text { daylight availability }\end{array}$ \\
\hline Li et al. (2006) & $\begin{array}{l}\text { open plan office } \\
\text { (Hong Kong) }\end{array}$ & d & all lights on & $33 \%$ \\
\hline $\begin{array}{l}\text { Lee and Selkowitz } \\
\text { (2006) }\end{array}$ & $\begin{array}{l}\text { open plan office } \\
\text { mock up (US) }\end{array}$ & d, blinds & lights on all day & $\begin{array}{l}\text { dependent on office hours but } \\
\text { up to } 59 \% \text { for bilateral sidelit } \\
\text { and } 23 \% \text { sidelit }\end{array}$ \\
\hline $\begin{array}{l}\text { Galasiu et al. } \\
(2007)\end{array}$ & $\begin{array}{l}\text { deep plan office } \\
\text { building (Canada) }\end{array}$ & $\begin{array}{l}\mathrm{o}, \mathrm{d} \\
\text { manual } \\
\text { dimming }\end{array}$ & $\begin{array}{l}\text { lights on continually for } \\
\text { work hours }\end{array}$ & in combination $42-47 \%$ \\
\hline $\begin{array}{l}\text { Fernandes et al. } \\
\text { (2014) }\end{array}$ & $\begin{array}{l}\text { large office } \\
\text { multi-occupancy } \\
\text { (US) }\end{array}$ & $o+d$ & $\begin{array}{l}\text { ASHRAE standard } \mathrm{W} / \mathrm{m}^{2} \\
\text { and scheduled } \\
\text { occupancy hours }\end{array}$ & in combination $47 \%$ \\
\hline Krarti et al. (2005) & $\begin{array}{l}\text { Simulated } \\
\text { large office (US) }\end{array}$ & $d$ & lights on continually & $\begin{array}{l}\text { up to } 70 \% \text { depending on } \\
\text { window area and site location }\end{array}$ \\
\hline $\begin{array}{l}\text { Vasilakopoulou et } \\
\text { al. (2016) }\end{array}$ & $\begin{array}{l}\text { various single } \\
\text { occupancy rooms } \\
\text { (Europe) }\end{array}$ & d & lights on all daylit hours & up to $94 \%$ \\
\hline
\end{tabular}




\subsection{Studies of spaces where individual switching may be used}

Studies have been published involving offices of a size where it would be reasonable to allow for individual manual switching. Nonetheless many of these studies chose to report energy savings relative to an assumption that lighting would have been left on all day. Amongst the studies that examined real buildings, Rubinstein and Karayel (1984) examined two office buildings, one in New York and one in San Francisco, and used respectively 18 and 16 hours per day for assumed operation of the lighting without the use of controls. This was based on the observation of how, in each building, lighting for the whole area was conventionally switched by security staff only. Individual switching of perimeter cellular offices was not considered. Consequently, simply scheduling the switching to fit with occupancy pattern made significant savings between 10 and $40 \%$. Separately the savings from automated controls ranged from 25 to 35\%. Maniccia et al. (1999) separately identified additional $15 \%$ savings arising from manual switching used in conjunction with $46 \%$ savings from occupancy sensing relative to constant lighting use in private offices within a large office building for a working day 08:00 to 18:00. The data were collected from December to March, but were not annualised. These illustrate the potential for over reporting of energy saving from automatic controls if the existing benefit of manual control is overlooked. Knight (1999) did not consider the duration of lighting use, instead focussing on changes to average power: thus percentage savings were implicitly related to an assumption of $100 \%$ use continually. Garg and Bansal (2000) investigated the benefits of an occupant movement sensor having a variable switch off delay, so that this delay might be minimised while avoiding occupant complaints from false "off" problems. Savings were calculated based on a comparison with lights being on all day. Onaygil and Güler (2003) set up monitoring in a test office in Istanbul and collected data on the performance of daylight-linked dimming control during each month of a whole year. Performance under different sky conditions was compared and an overall $31 \%$ saving reported for the whole year.

Collectively these case studies, summarised in Table 5 suggest median savings potential from occupancy sensing or daylight sensing based controls of $46 \%$ so not dissimilar to those reported for 
larger offices spaces without individual control, as shown in Table 4, when referenced to continuous lighting use. However, where the effect of manual control is measured the savings from automatic control necessarily look smaller. For example, a study by Newsham et al. (2008) observed forty users occupying a daylit office laboratory for one day each. The study investigated the choices individuals make given individual control of lighting dimming and regular prompts to reset the controls, and energy used over a working day was found on average to be $25 \%$ less than the lighting controlled to produce a constant 500 lux. Thus the daylight savings from daylight related dimming were implicitly included in the base case. The reported $25 \%$ saving then related to the additional saving from individuals electing to work in lower illuminance levels

Littlefair (1998) has described techniques for predicting energy use under different control regimes, but still referred to continuous use in the assessment of savings potential. In other space specific studies utilising simulation of energy use (Acosta et al., 2015; Papatinou et al., 2016; Roisin et al., 2008), again a wider range of possible scenarios were explored, but still the baseline for savings estimation was an assumed constant lighting use. In the case of Acosta et al. (2015) the range of variables: time of day, window dimensions and position, internal surface reflectance values, maintained workplane illuminance and latitude of office location, provides a very large number of simulated cases. Power consumption for each is calculated assuming perfect dimming control to maintain constant illuminance. 
Table 5 Studies in single buildings with prospect of individual switching using continuous full load as baseline

\begin{tabular}{|c|c|c|c|c|}
\hline Reference & Application & $\begin{array}{l}\text { Control or saving } \\
\text { method } \\
o=\text { occupancy sensing } \\
d=\text { daylight-linked } \\
\text { dimming }\end{array}$ & Baseline & Savings reported \\
\hline $\begin{array}{l}\text { Rubinstein and } \\
\text { Karayel (1984) }\end{array}$ & $\begin{array}{l}\text { Measured } \\
\text { large office spaces } \\
\text { including private offices } \\
\text { (US) }\end{array}$ & $d$ & $\begin{array}{l}\text { lights on } 18 \mathrm{~h} \text { or } 16 \mathrm{~h} \\
\text { per day }\end{array}$ & $25-35 \%$ \\
\hline $\begin{array}{l}\text { Maniccia et al. } \\
\text { (1999) }\end{array}$ & large office (US) & o & lights on continually & $46 \%$ \\
\hline Knight (1999) & seminar room (UK) & $d$ & $\begin{array}{l}\text { no consideration of } \\
\text { hours of use }\end{array}$ & $\begin{array}{l}\text { up to } 76 \% \text { power } \\
\text { saving }\end{array}$ \\
\hline $\begin{array}{l}\text { Garg and Bansal } \\
(2000)\end{array}$ & $\begin{array}{l}\text { laboratory set up of } \\
\text { single occupant office }\end{array}$ & o (variable delay) & lights on all day & $\begin{array}{l}25 \% \\
\text { (as opposed to } 20 \% \\
\text { for ordinary sensor) }\end{array}$ \\
\hline $\begin{array}{l}\text { Onaygil and } \\
\text { Güler (2003) }\end{array}$ & small office (Istanbul) & $d$ & lights on continually & $31 \%$ \\
\hline $\begin{array}{l}\text { Newsham et al. } \\
\text { (2008) }\end{array}$ & small office (Canada) & manual dimming & $\begin{array}{l}\text { lighting set to deliver } \\
500 \text { Ix continually }\end{array}$ & $25 \%$ \\
\hline $\begin{array}{l}\text { Roisin et al. } \\
\text { (2008) }\end{array}$ & $\begin{array}{l}\text { Simulated } \\
\text { office }\end{array}$ & $o, d$ & $\begin{array}{l}\text { lights on all occupied } \\
\text { hours }\end{array}$ & $\begin{array}{l}45-61 \% \\
\text { depending on } \\
\text { orientation and } \\
\text { location }\end{array}$ \\
\hline $\begin{array}{l}\text { Acosta et al. } \\
(2015)\end{array}$ & office & $\begin{array}{l}\mathrm{d} \text { with variation in } \\
\text { window area, and } \\
\text { positioning }\end{array}$ & $\begin{array}{l}\text { maintaining } \\
\text { continuous } 500 \text { lux }\end{array}$ & $\begin{array}{l}6-88 \% \text { for different } \\
\text { cases }\end{array}$ \\
\hline $\begin{array}{l}\text { Papatinou et al. } \\
(2016)\end{array}$ & $\begin{array}{l}\text { hospital waiting rooms } \\
\text { (Italy and Greece) }\end{array}$ & $0, d$ & $\begin{array}{l}\text { current use of } \\
\text { artificial lighting }\end{array}$ & $\begin{array}{l}11-54 \% \text { depending } \\
\text { on room }\end{array}$ \\
\hline
\end{tabular}

Researchers in some studies elect to assess the energy use under manual control, and use this as the basis for evaluating additional savings from automated control. Crisp, Littlefair, Cooper and McKennan (1988) used Hunt's method in a simulation of office lighting energy use. Jennings et al. (2000) took advantage of a renovation of an office building in San Francisco to test a range of lighting control methods in private offices on two of the floors. Data were collected over a period June to December, so their results can be extrapolated to estimate annual lighting use. The floor areas in the test were segregated with different forms of control so that the effects can be calculated for occupancy sensing, manual dimming and daylight-linked dimming. On average per day lighting was switched on, according to which floor, between 8.4-8.9 hours per day. As the use of wall-mounted manual switches was monitored, the energy use could be compared with the 
consumption associated with the hours that the switch was on. Von Neida et al. (2001) collected data from sixty office sites spread across 24 American states. Data were collected between February and September; for each site, rooms were monitored for two weeks during this period with loggers installed to record occupancy and lighting use. All of the rooms in the study employed manual control only. The patterns of occupancy were then used to model the effect of occupancy sensing would have on lighting energy use with reported savings varying 28 to $38 \%$ depending on the time delay settings.

Reinhart (2004) developed a model, Lightswitch 2002, to predict the use of lighting controls and window blinds, and used this to model the lighting energy use in a hypothetical small office space. The switch-on probability for manual switching was modelled using predictions of internal daylight illuminance as Hunt (1980) and Love (1998), and this allowed additional saving from other forms of control to be predicted. In the case of purely occupancy sensing control the energy use was found to be greater than for manual switching. Savings were only achieved if automatic controls complimented manual switching. Chiogna, Mahdavi, Albatici and Frattari (2012) compared recorded lighting energy use in teaching rooms with automatic control and with manual control. Savings were calculated having corrected for differences in occupancy and illuminance levels. Results are summarised in Table 6 and the median savings reported are $30.5 \%$. 
Table 6 Studies using manual control as baseline

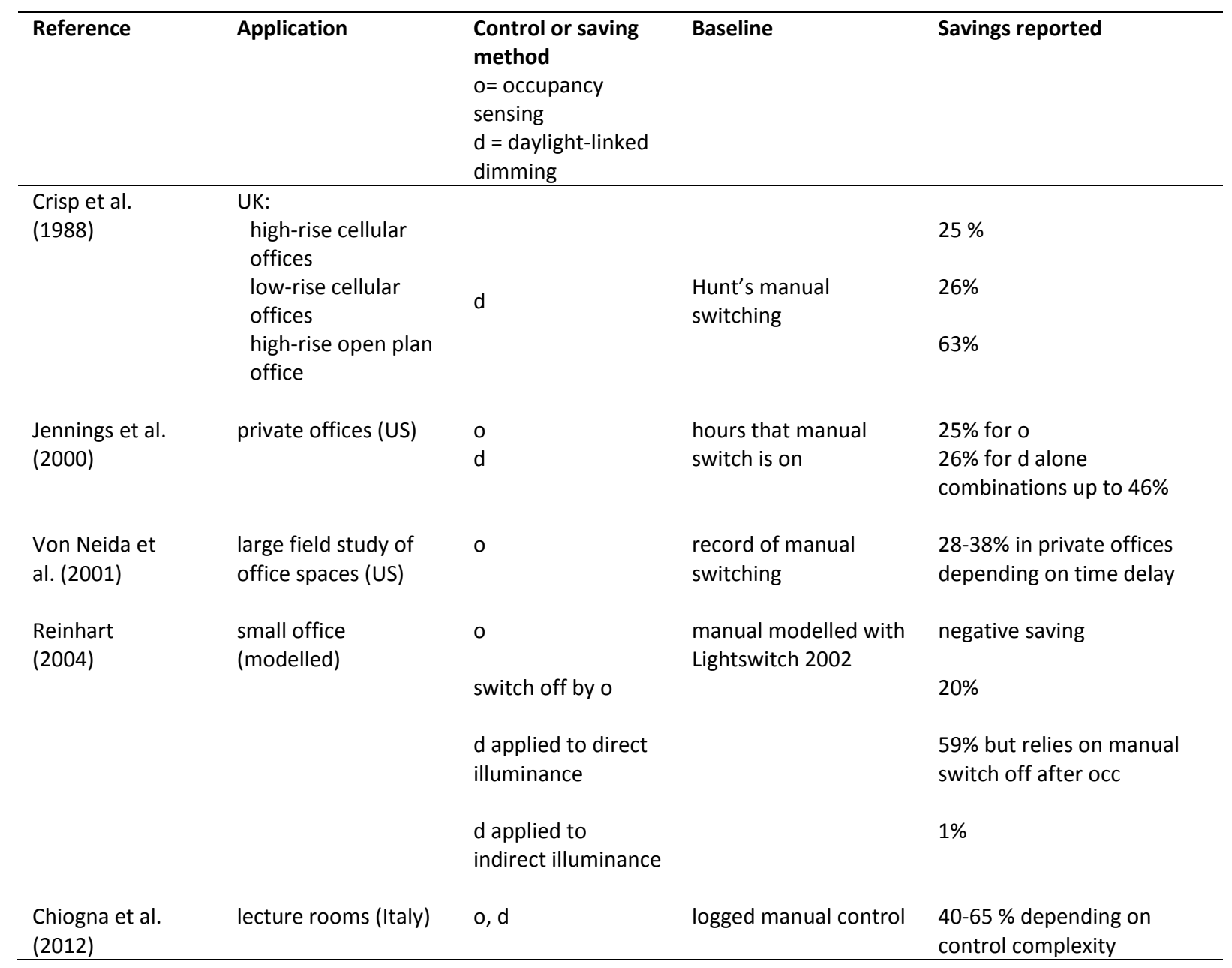

\subsection{Selected comparisons using Hunt's estimation of manual control use}

In a limited number of the studies there is sufficient detail given about the rooms for an assessment to be made using Hunt's data (1980) for the energy use expected from the use of manual switching. The study by Roisin et al. (2008) employed the free design software package Dialux to determine the artificial lighting design. Similarly, Dialux may be used to assess minimum daylight factors to use with Hunt's data, and these are shown in Table 7 alongside Hunt's probability of switching on at arrival. These probabilities are taken to be the annual probability of lights being used, as Hunt demonstrated that for most users there was very little intermediate switching during the day. In this way, an assessment was made of the annual lighting energy use under simple manual control. By setting this against the savings data quoted in earlier studies, it was possible to reconsider the level of saving using manual switching as the baseline. The simulations considered by Acosta et al. (2015) 
covered a very large number of combinations of different variables; for this comparison one case has been considered: square window, centrally positioned, filling $60 \%$ of the façade, with the room placed at $50^{\circ}$ latitude and assuming 8 am start.

Table 7 Calculated minimum room daylight factors and manual switching probability

\begin{tabular}{|c|c|c|c|c|}
\hline \multirow[t]{2}{*}{ Reference } & & \multirow{2}{*}{$\begin{array}{l}\text { Minimum orientation corrected } \\
\text { DF }\end{array}$} & \multicolumn{2}{|c|}{$\begin{array}{c}\text { Hunt's annual probability of switching } \\
\text { on }\end{array}$} \\
\hline & & & 8 am start & 9 am start \\
\hline \multicolumn{2}{|l|}{ Knight (1999) } & $0.69 \%$ & $68 \%$ & $53 \%$ \\
\hline \multicolumn{2}{|c|}{ Onaygil and Güler (2003) } & $0.43 \%$ & $77 \%$ & $65 \%$ \\
\hline Maniccia et al. & $\mathrm{N}$ & $1.68 \%$ & $50 \%$ & \\
\hline (1999) & $\mathrm{E}$ & $1.27 \% *$ & $55 \%$ & \\
\hline \multirow[t]{2}{*}{ perimeter offices } & $\mathrm{S}$ & $1.34 \% *$ & $54 \%$ & NA \\
\hline & w & $1.41 \% *$ & $52 \%$ & \\
\hline \multirow[t]{2}{*}{$\begin{array}{l}\text { Newsham et al. } \\
(2008)\end{array}$} & $\begin{array}{l}0.2 \\
\text { bound }\end{array}$ & $0.19 \%$ & NA & $84 \%$ \\
\hline & $\begin{array}{l}0.5 \\
\text { bound }\end{array}$ & $0.24 \%$ & NA & $79 \%$ \\
\hline \multirow[t]{4}{*}{ Roisin et al. (2008) } & $\mathrm{N}$ & $0.17 \%$ & $93 \%$ & $87 \%$ \\
\hline & $\mathrm{E}$ & $0.23 \%$ & $89 \%$ & $80 \%$ \\
\hline & $\mathrm{S}$ & $0.26 \%$ & $87 \%$ & $78 \%$ \\
\hline & W & $0.22 \%$ & $90 \%$ & $82 \%$ \\
\hline
\end{tabular}

Notes: *includes external light shelf.

In all cases, as shown in Table 8, the estimated reduction in energy from employing manual switching is significant compared to, and sometimes greater than, the savings identified from the automatic control methods. Median values for the reported savings were $42.5 \%$ while the median for Hunt's assessment was 30.5\%. However, it should be noted that the comparison concerns automatic control supplanting rather than supplementing manual switching. 
Table 8 Reported automatic control savings and estimated manual control savings

\begin{tabular}{llll}
\hline Reference & Baseline & Reported savings & Manual switching saving \\
\hline Knight (1999) & no consideration of hours of use & up to $76 \%$ power saving & up to $47 \%$ \\
$\begin{array}{l}\text { Onaygil and Güler } \\
(2003)\end{array}$ & lights on continually & up to $30 \%$ & up to $35 \%$ \\
$\begin{array}{l}\text { Maniccia et al. } \\
\text { (1999) }\end{array}$ & lights on continually & $46 \%$ & $\begin{array}{l}47 \% \text { as mean of perimeter } \\
\text { orientations }\end{array}$ \\
$\begin{array}{l}\text { Newsham et al. } \\
\text { (2008) }\end{array}$ & $\begin{array}{l}\text { lighting set to deliver 500 lux } \\
\text { continually }\end{array}$ & $25 \%$ & $21 \%$ \\
Roisin et al. (2008) & lights on all occ hours & $\begin{array}{l}45-61 \% \\
\text { depending on orientation and } \\
\text { location }\end{array}$ & $\begin{array}{l}7-22 \% \text { depending on } \\
\text { orientation }\end{array}$ \\
& & $39 \%$ & $26 \%$ \\
\hline
\end{tabular}

\section{Larger field studies}

In the study of the impact of occupancy sensors on lighting energy use reported in Table 6, Von Neida et al. (2001) selected sixty organisations active in the US Energy Protection Agency's Green Lights Program and spread over 24 US states. The purpose of the study was to investigate lighting use and space occupancy patterns in various commercial buildings to improve estimates of the energy saving from using occupancy sensors. Critically, the study included the assessment of the use of manual controls. None of the spaces monitored used automatic controls, and the effect of occupancy sensing was simulated assuming different values for the timeout settings. Monitoring was carried out over two-week periods and data were used from 158 different rooms, 37 of which were private offices. Occupancy and lighting use were monitored and the occupancy patterns used in the simulation. Data from weekdays and weekends were aggregated to determine the average percentage of time that spaces were occupied with lights on or off, and unoccupied with lights on. For private offices the time broke down as spaces occupied $18 \%$ of the time, and lights on $33 \%$ of the time, suggesting that the manual controls had permitted significant energy waste. No sinusoidal annualisation was used but sites were monitored at various times between February and September, so extrapolation might be attempted with caution. This would lead to estimated annual 
hours of use of 2890 . This is high compared with other studies with hours of use approaching total occupied hours spread over weekdays and weekends. They report that $86 \%$ of the lighting energy use was recorded on weekdays, suggesting that weekday hours of use would have been 2485 . Also, it was noted that $11 \%$ of the energy use was during the "night" hours 18:00 to $06: 00$, which indicates that despite the availability of manual controls, switching was carried out primarily outside of the office working period, perhaps by security or cleaning staff.

A number of large field studies have been carried out in the US to assess the impacts of demand side management by lamp replacement (EMI Consulting, 2013, 2014; Itron, 2010; Kema Inc., 2010). Typically the schemes entail subsidised cost of lamps through upstream incentive programmes that work through manufacturers and distributors. The purpose of the reported studies was evaluation, measurement, and verification of these energy efficiency programmes. In order to assess total energy savings, hours of use were first logged for individual luminaires. Data collected over a period of months was then annualised to provide annual hours of use. Data were aggregated over many premises, so they give an average, disregarding individual differences in any aspects of the premises. These results may provide a more valid indication of typical lighting use, where the emphasis has not been on automating controls, but reducing light power. The analyses were expressly intended for large samples, often there is large variance amongst the individual cases and therefore it is not likely to be accurate for individual premises. However, the data can provide some useful benchmarks, and these are summarised in Table 9.

Table 9 Annual hours of lighting use reported in large field studies

\begin{tabular}{|c|c|c|c|c|c|}
\hline Reference & Location & Application & Control or saving method & $\begin{array}{l}\text { Size of } \\
\text { sample }\end{array}$ & Hours of use \\
\hline $\begin{array}{l}\text { Kema Inc. (2010), } \\
\text { Itron (2010) }\end{array}$ & California & $\begin{array}{l}\text { small } \\
\text { commercial }\end{array}$ & $\begin{array}{l}\text { lamp replacement (CFL and } \\
\text { LED) }\end{array}$ & $>1000$ sites & $\begin{array}{l}2191-2710 \\
\text { depending on utility } \\
\text { area }\end{array}$ \\
\hline $\begin{array}{l}\text { EMI Consulting } \\
(2014)\end{array}$ & $\begin{array}{l}\text { Michigan } \\
\text { state }\end{array}$ & offices & $\begin{array}{l}\text { in anticipation of future } \\
\text { saving implementation }\end{array}$ & 31 offices & 1974 \\
\hline $\begin{array}{l}\text { Von Neida et } \\
\text { al.(2001) }\end{array}$ & $\begin{array}{l}24 \text { US } \\
\text { states }\end{array}$ & commercial & occupancy control & 37 rooms & $2890 *$ \\
\hline
\end{tabular}

Notes: *estimated from fortnight monitoring. 
For the study carried out in California, Kema Inc. (2010) collated data from both residential and small commercial promises. Usage data were collected using data loggers that record for how long lamps were emitting flux. For the residential sites they generated an ANCOVA model to relate annualised hours of use to dwelling unit characteristic, room type, fixture type, lamp type, and electricity utility company. This could allow particular premises to be benchmarked according to its characteristics. In Michigan State, EMI Consulting (2014) monitored lighting use in 180 premises, of which 31 were offices and 20 were industrial or warehousing units. The objective was to update the data held in the existing Michigan Energy Measures Database, which is used for assessing the impact of energysaving measures. The monitoring period average 42 days, and weekdays and weekends were examined separately. In addition to the hours of use, data were collected on the ratio of hours of use to operating hours, which had average values of $79 \%$ for offices, $96 \%$ for industrial premises and $78 \%$ for warehouses. With the exception of warehousing, the hours of use are markedly lower than those assumed in the previous version of the Michigan Energy Measures Database, which used a set value of 3680 for annual hours of use for non-high bay lighting. The data collected from the different sites were also separated by space type within each of the premises. Within the set of data for office premises, open area office spaces had 1671 and small offices spaces had 2378 annual hours of use on average. Very few of the offices employed any automated lighting controls, but a comparison between premises with and without controls was the subject of a separate study (EMI Consulting, 2013). This additional study compared sites that had occupancy sensor controlled lighting with those without. Included in the study were 61 office premises without this lighting control and 50 with. The hours of use were calculated as a proportion of facility operating hours, and this was reduced in the controlled sites by only 0.038 . Larger reductions of 0.542 were found for industrial premises. 


\section{Discussion}

A comparison between the sets of published results can be made to determine if there is evidence of systematic over-estimation of energy savings benefits of automatic lighting controls. This should be prefaced with a warning that these comparisons are not based on random sampling. Because they are based on published studies, they are likely to suffer publication bias in favour of illustrating energy savings benefits. Thus they can be understood to represent the best case for the energy saving potential of the automated lighting controls.

The median values for the reported savings from the different sets of studies are reproduced in Table 10, and these provide further support for believing that energy savings are being overstated. Therefore, in assessing relative projected benefits for various lighting control methods there is need to account for the reduced energy consumption expected from use of any manual switching.

\section{Table $10 \quad$ Median energy savings reported}

\begin{tabular}{lc}
\hline & Median saving \\
\hline Table 4: Cases without manual switching & $50 \%$ \\
Table 5: Cases with manual switching ignored & $46 \%$ \\
Table 6: Cases where manual switching is the reference & $32 \%$ \\
\hline
\end{tabular}

The impact of manual switching in a particular case will depend on the degree to which manual control is appropriate, in turn depending for example on the balance between small offices under individuals' control and large open plan spaces. This may be determined in individual cases, but may not be generalizable. To compare with data derived from large surveys measuring hours of use, it is useful to convert reported savings into an equivalent full-load annual hours of use value. For this purpose it is assumed that normal office hours of use are 08:00-18:00 over 5-day week, thus 2600 hours per annum. So taking for example the median of the savings calculated using Hunt's method of $30.5 \%$ it might be expected that annual hours of use would typically be about 1800 before any automated controls are used. In individual buildings user behaviour varies greatly so data from small 
samples are unlikely to suffice as a basis for a reliable benchmark. Comparison with the results from field studies shown in Table 9 demonstrates that this might not be generalizable. The field studies, representing a wider range of actual promises, may exploit manual switching to a lesser degree, and there may be national differences in office space usage between the US where the studies were carried out and UK where Hunt conducted his work. However, data from field studies or from nationally accepted benchmarks might be taken as the locally agreed basis for making lighting energy use comparisons.

\section{Conclusion}

Lighting energy use varies greatly between different commercial buildings. It is an important component of each building's energy performance and improved control measures can contribute to reductions in associated carbon emissions. In the design of, and promotion of the use of, automatic lighting controls the projected energy savings frequently need to be established. Likewise projected savings are important when novel methods are investigated by the research community, for whom results of comparisons need to be unambiguous. However, it has been shown that published studies risk overstating savings potential, and that in some case the use of automatic control systems may not save energy at all.

Prediction of actual energy use from automated controls is likely to be reliable as models are largely deterministic, and do not need to regard the uncertainty of occupant behaviour. In many commercial premises manual control is a realistic possibility and user behaviour is a critical determinant of lighting use. Then the determination of energy savings is more difficult as it is subject to the stochastic behaviour of occupants. Automatic control is effectively modelled in proprietary energy modelling software packages, but manual control is not. This paper demonstrates that the reduction in energy use resulting from manual switching is not insignificant and needs to be accounted for in some way in the assessment of energy-saving potential. There is a need to clarify the basis for calculation of energy savings, and for comparison purposes some 
standard basis for comparison is needed. Large field studies or recognised national benchmark data may be the only generalizable reference for making comparisons.

Additionally, some clarification is needed when assessing savings from automated controls relative to assumed manual switching as to whether the automated control supplants or supplements manual control. The presence of automatic control has been shown to alter the switching behaviour of occupants.

In future lighting control studies the risk of overstating savings potential would be reduced if only energy use was reported for automatic control methods as the modelling is likely to be deterministic and based on quantifiable aspects such as controller law and illuminance values, especially if using standard weather data in climate-based daylight modelling, for example. Where an energy saving benefit needs to be evaluated then the user switching behaviour needs to be modelled, or reference made to reference data such as field studies or national benchmarks adjusted for actual operating hours. It is unrealistic to report simple percentage saving values for control methods. 


\section{References}

Acosta, I., Munoz, C., Campano, M.A., \& Navarro, J. (2015). Analysis of daylight factors and energy saving allowed by windows under overcast sky conditions. Renewable Energy, 77, 194-207.

doi:10.1016/j.renene.2014.12.017

Boyce P.R., Veitch J.A., Newsham G.R., Jones C.C., Heerwagen J., Myer M., \& Hunter C.M. (2006). Occupant use of switching and dimming controls in offices. Lighting Research and Technology, 38, 358-378. doi:10.1177/1477153506070994

BSI (2007). BS EN 15193:2007 Energy performance of buildings - Energy requirements for lighting. British Standards Institute.

Chiogna, M., Mahdavi, A., Albatici, R., \& Frattari, A. (2012) Energy efficiency of alternative lighting control systems. Lighting Research and Technology, 44, 397-415. doi:10.1177/1477153511427427

CIBSE (2012). Guide F: Energy efficiency in buildings. London: Chartered Institution of Building Services Engineers.

Crisp, V.H.C. (1978). The light switch in buildings. Lighting Research and Technology, 10, 69-82. doi: 10.1177/096032717801000202

Crisp, V.H.C, Littlefair, P.J., Cooper, I., \& McKennan, G. (1988). BRE Report 129: Daylighting as a passive solar energy option: an assessment of its potential in on-domestic buildings. Garston: Building Research Establishment.

DECC (2015). Energy consumption in the United Kingdom (2014 data tables) London: Department of Energy and Climate Change. Retrieved from https://www.gov.uk/government/statistics/energyconsumption-in-the-uk (accessed June 2016)

EMI Consulting (2013). Commercial Lighting Controls Metering Study. Presentation dated June 18, 2013. Retrieved July1, 2016 from:

http://www.dleg.state.mi.us/mpsc/electric/workgroups/progdesign/lcs ce 201306 16.pdf

EMI Consulting (2014). Michigan Statewide Commercial and Industrial Lighting Hours-of-Use Study. Retrieved June 30, 2016 from:

http://www.michigan.gov/documents/mpsc/ci memd com lighting hou studydraftrpt 4589817. pdf

Fernandes, L.L., Lee, E.S., DiBartolomeo, D.L., \& McNeil, A. (2014) Monitored lighting energy savings from dimmable lighting controls in The New York Times Headquarters Building. Energy and Buildings, 68, 498-514. doi:10.1016/j.enbuild.2013.10.009

Gaetani, I., Hoes, P.-J., \& Hensen J.L.M. (2016). Occupant behavior in building energy simulation: Towards a fit-for-purpose modeling strategy. Energy and Buildings, 121, 188-204. doi: 10.1016/j.enbuild.2016.03.038

Galasiu, A.D., Newsham, G.R., Suvagau, C., \& Sander, D.M. (2007) Energy Saving Lighting Control Systems for Open-Plan Offices: A Field Study. LEUKOS, 4, 7-29. doi:10.1582/LEUKOS.2007.04.01.001 
Garg, V. \& Bansal, N. K. (2000) Smart occupancy sensors to reduce energy consumption. Energy and Buildings, 32, 81-87. doi:10.1016/S0378-7788(99)00040-7

Hunt, D.R.G. (1979). The Use of Artificial Lighting in Relation to Daylight Levels and Occupancy. Building and Environment, 14, 21-33. doi:10.1016/0360-1323(79)90025-8

Hunt, D.R.G. (1980). Predicting artificial lighting use - a method based upon observed patterns of behaviour. Lighting Research and Technology, 12, 7-14. doi:10.1177/096032718001200102

International Energy Agency. (2013). Technology Roadmap: Energy Efficient Building Envelopes, Paris: International Energy Agency. Retrieved May 10, 2016 from:

http://www.iea.org/publications/freepublications/publication/TechnologyRoadmapEnergyEfficientB uildingEnvelopes.pdf

Itron (2010). Small Commerical Contract Group Direct Impact Evaluation Report Final Report Executive Summary. Retrieved June 30, 2016 from:

https://www.itron.com/PublishedContent/101325WP01\%20Small\%20Commercial\%20Contract\%20Group.pdf

Jennings, J.D., Rubinstein, F.M., DiBartolomeo, D., \& Blanc, S.,L. (2000). Comparison of Control Options in Private Offices in an Advanced Lighting Controls Testbed. Journal of the Illuminating Engineering Society, 29, 39-60, doi:10.1080/00994480.2000.10748316

KEMA, Inc. (2010). Final Evaluation Report: Upstream Lighting Program Volume 1. Retrieved June 30, 2016 from:

http://www.energydataweb.com/cpucfiles/18/finalupstreamlightingevaluationreport 2.pdf

Knight, I.P. (1999). Measured energy savings due to photocell control of individual luminaires.

Lighting Research and Technology, 31, 19-22. doi: 10.1177/096032719903100104

Krarti, M., Erickson, P.M., \& Hillman, T.C. (2005) A simplified method to estimate energy savings of artificial lighting use from daylighting. Building and Environment, 40, 747-754.

doi:10.1016/j.buildenv.2004.08.007

Lee, E.S., \& Selkowitz, S.E. (2006). The New York Times Headquarters daylighting mockup: Monitored performance of the daylighting control system. Energy and Buildings 38, 914-929.

doi:10.1016/j.enbuild.2006.03.019

Li, D.H.W., \& Lam, J.C. (2001). Evaluation of lighting performance in office buildings with daylighting controls. Energy and Buildings, 33, 793-803. doi: 10.1016/S0378-7788(01)00067-6

Li, D.H.W., Lam, T.N.T, \& Wong, S.L. (2006). Lighting and energy performance for an office using high frequency dimming controls. Energy Conversion and Management, 47, 1133-1145.

doi:10.1016/j.enconman.2005.06.016

Lindelöf, D. \& Morel, N. (2006). A field investigation of the intermediate light switching by users.

Energy and Buildings, 38, 790-801. doi:10.1016/j.enbuild.2006.03.003 
Littlefair, P.J. (1990). Predicting Annual Lighting use in Daylit Buildings. Building and Environment, 25, 43-53. doi:10.1016/0360-1323(90)90040-X

Littlefair, P.J. (1998). Predicting lighting energy use under daylight linked lighting controls. Building Research \& Information, 26:4, 208-222, doi:10.1080/096132198369823

Littlefair, P.J. (2014). BRE Digest 498: Selecting lighting controls. Garston: Building Research Establishment.

Love, J.A. (1998). Manual switching patterns in private offices. Lighting Research and Technology, 30, 45-50. doi:10.1177/096032719803000107

Maniccia, D., Rutledge, B., Rea, M.S., \& Morrow, W. (1999) Occupant Use of Manual Lighting Controls in Private Offices. Journal of the IlluminatingEngineering Society, 28, 42-56.

doi:10.1080/00994480.1999.10748274

Moore, T., Carter, D.J., and Slater, A.I. (2002). A field study of occupant controlled lighting in offices. Lighting Research and Technology, 34, 191-205. doi: 10.1191/1365782802/t047oa

Nagy, Z., Yong, F.Y., Frei, M., \& Schlueter, A. (2015). Occupant centered lighting control for comfort and energy efficient building operation. Energy and Buildings 94, 100-108.

doi:10.1016/j.enbuild.2015.02.053

NBS. (2013). Non-Domestic Building Services Compliance Guide. Retrieved from:

https://www.gov.uk/government/uploads/system/uploads/attachment data/file/453973/non dom estic building services compliance guide.pdf

Newsham, G.R., Aries, M.B.C., Mancini, S. \& Faye, G. (2008). Individual control of electric lighting in a daylit space. Lighting Research and Technology 40, 25-41. doi:10.1177/1477153507081560

NMR Group Inc., (2014). Northeast Residential Lighting Hours-of-Use Study. Retrieved June 30, 2016 from http://www.neep.org/northeast-residential-lighting-hours-use-study

Onaygil, S. \& Güler, Ö. (2003). Determination of the energy saving by daylight responsive lighting control systems with an example from Istanbul. Building and Environment 38, 973 - 977.

doi:10.1016/S0360-1323(03)00034-9

Papantoniou, S., Kolokotsa, D., Kalaitzakis, K., Cesarini, D.N., Cubi, E., \& Cristalli, C. (2016). Adaptive lighting controllers using smart sensors. International Journal of Sustainable Energy, 35, 537-553. doi:10.1080/14786451.2014.923887

Reinhart, C.F. (2004). Lightswitch-2002: a model for manual and automated control of electric lighting and blinds. Solar Energy, 77, 15-28. doi:10.1016/j.solener.2004.04.003

Reinhart, C.F., \& Voss, K. (2003). Monitoring manual control of electric lighting and blinds. Lighting Research and Technology, 35, 243-260. doi:10.1191/1365782803li064oa

Roisin, B., Bodart, M., Deneyer, A., \& D’Herdt, P. (2008). Lighting energy savings in offices using different control systems and their real consumption. Energy and Buildings, 40, 514-523.

doi:10.1016/j.enbuild.2007.04.006 
Rubinstein, F.M., \& Karayel, M. (1984). The Measured Energy Savings from Two Lighting Control Strategies. IEEE Transactions on Industry Applications, IA-20, 1189-1197.

doi:10.1109/TIA.1984.4504582

Shepherd, B., Rambo, E., \& Busker, M. (2013, August) Annualization of Results of Residential Lighting Meter Data. Paper presented at International Energy Program Evaluation Conference, Chicago, IL.

Sorrell, S. (2009). Jevons' Paradox revisited: The evidence for backfire from improved energy efficiency. Energy Policy, 37 1456-1469. doi:10.1016/j.enpol.2008.12.003

Tzempelikos, A. (2010, July). The impact of manual light switching on lighting energy consumption for a typical office building. Paper presented at International High Performance Buildings Conference, Purdue, IN.

Vasilakopoulou, K., Synnefa, A., Kolokotsa, D., Karlessi, T., \& Santamouris, M. (2016) Performance prediction and design optimisation of an integrated light pipe and artificial lighting system.

International Journal of Sustainable Energy, 35, 675-685. doi: 10.1080/14786451.2014.932281

Von Neida, B., Maniccia, D., \& Tweed, A. (2001) An Analysis of the Energy and Cost Savings Potential of Occupancy Sensors for Commercial Lighting Systems. Journal of the Illuminating Engineering Society, 30, 111-125. doi:10.1080/00994480.2001.10748357

Williams, A., Atkinson, B., Garbesi, K., Page, E., \& Rubinstein, F. (2012) Lighting Controls in Commercial Buildings, LEUKOS, 8, 161-180. doi:10.1582/LEUKOS.2012.08.03.001 